\title{
Age-standardized mortality rates related to viral hepatitis in Brazil
}

\author{
Hugo Perazzo ${ }^{1 *}$, Antonio G Pacheco ${ }^{2}$, Paula M Luz', Rodolfo Castro ${ }^{1}$, Chris Hyde ${ }^{3}$, Juliana Fittipaldi ${ }^{1}$, \\ Caroline Rigolon ${ }^{1}$, Sandra W Cardoso ${ }^{1}$, Beatriz Grinsztejn ${ }^{1}$ and Valdiléa G Veloso ${ }^{1}$
}

\begin{abstract}
Background: Liver-related mortality has been increasing worldwide. We aimed to estimate the age-standardized mortality rates from viral hepatitis in Brazil.

Methods: The Brazilian National Death Registry was analyzed from 2008 to 2014. Viral hepatitis deaths were defined by the following ICD-10 codes in the death certificate: hepatitis A [B15.0; B15.9]; hepatitis B [B16.2; B16.9; B18.1]; hepatitis C [B17.1; B18.2]; hepatitis Delta [B16.0; B16.1; B18.0; B17.0] and other viral hepatitis [B17.2; B17.8; B18.8; B18. 9; B19.0; B19.9]. Crude mortality rates were calculated by the ratio between total number of deaths and estimated population. Mortality rates were age-standardized by the direct method using the WHO standard population.

Results: Thirty four thousand, nine hundred seventy eight deaths had viral hepatitis mentioned in their death certificate [65\% male, aged 58 years, 73\% associated with hepatitis C]. Age-standardized mortality rate (95\% Cl) due to viral hepatitis was 2.695 (2.667-2.724) deaths per 100,000 inhabitants: South region had the higher rates [3.997 (3.911-4.085)]. Mortality rates associated with hepatitis A and Delta were $0.032(0.029-0.035)$ and $0.028(0.025-0.031)$, respectively. Hepatitis $C$ mortality rates were 4 -fold higher than those associated with hepatitis B [1.964 (1.940-1.989) vs 0.500 (0.488-0.512)]. South region had the higher rates for hepatitis C [3.163 (3.087-3.241)] and North had the higher rates for hepatitis A [0.066 (0.049-0.087)], B [0.986 (0.918-1.058)] and Delta [0.220 (0.190-0.253)].
\end{abstract}

Conclusion: Viral hepatitis remains a major public health issue in Brazil. Mortality rates were not homogeneous across the country, suggesting that health policies should be customized according to geographical location.

Keywords: Liver disease, Hepatitis, Death rates, Age-standardized mortality

\section{Background}

In the last years, liver-related mortality rates have been increasing worldwide [1]. Approximately 2 million cases of chronic liver diseases are expected in the next 40 years in Latin America [2]. Viral hepatitis might lead to fulminant liver failure and remains the main indication of liver transplantation due to acute or chronic liver disease [3]. Acute hepatitis A is generally self-limited and more severe disease occurs more frequently in elderly and individuals with immunodeficiency [4]. Hepatitis E infection causes large outbreaks and high mortality rates have been described in pregnant women [5]. Chronic infection by hepatitis $\mathrm{B}, \mathrm{C}$ and Delta virus leads to

\footnotetext{
* Correspondence: perazzohugo@gmail.com; hugo.perazzo@ini.fiocruz.br ${ }^{1}$ Fundação Oswaldo Cruz (FIOCRUZ), Instituto Nacional de Infectologia Evandro Chagas (INI), Laboratório de Pesquisa Clínica em DST e AIDS (LAPCLIN-AIDS), Rio de Janeiro, Brazil

Full list of author information is available at the end of the article
}

progression from minimal fibrosis to cirrhosis, the most frequent liver related death cause worldwide [1].

In Brazil, more than 130,000 new cases of acute and chronic viral hepatitis were registered by the health authorities from 2012-2015 (Sistema de Informação de Agravos de Notificação - SINAN - website: http://portalsinan.saude.gov.br/hepatites-virais) [6]. Data from the Ministry of Health (MoH) of Brazil estimated that 1.41.7 million people are chronically infected with hepatitis $\mathrm{C}$ virus (HCV) [7]. Presence of advanced fibrosis was reported in up to $30 \%$ of patients with hepatitis B and Delta coinfection in western Amazon Basin $[8,9]$ and more than 800,000 liver-related hospitalizations $(\sim 30,000$ admissions per year) were performed in the last decade in Brazil [10]. We previously reported a nationwide analysis describing an increase in number of deaths due to liver diseases and cirrhosis in the last decade 
[11]. The Viral Hepatitis National Program of the Brazilian $\mathrm{MoH}$ has been implementing strategies to prevent, early-diagnosis and treatment of viral hepatitis [12]. However, the burden of viral hepatitis might not be homogeneous across the country. Thus, the analysis of the geographical distribution the mortality rates related to viral hepatitis seems to be essential to prioritize or reinforce these health policies in hot spots of specific etiologies of viral hepatitis. The aim of this study was to estimate the age-standardized mortality rates related to viral hepatitis in Brazil and its micro and macro regions.

\section{Methods}

\section{Study design}

We analyzed the Brazilian National Death Registry database (Sistema de Informação sobre Mortalidade - SIM) from the Brazilian Unified Health System Information Technology Department (DATASUS) to estimate the mortality rates related to viral hepatitis in a 7-year period (from 2008 to 2014). The study protocol was approved with waiver of informed consent by the Ethical Committee from Instituto Nacional de Infectologia Evandro Chagas (IRB 51736815.3.0000.5262). Federative Units and macro-regions of Brazil were defined by the Brazilian Institute of Geography and Statistics (IBGE) as the Brazilian states and legally valid subnational units as North, Northeast, Central-West, Southeast and South regions, respectively.

\section{Mortality and population data collection}

The Brazilian $\mathrm{MoH}$ has an open-source and web available database, the Brazilian Death Registry (SIM), where all deaths causes have been registered based on the death certificate (DC) in Brazil since 1979. Anonymous data have been published in a public domain (http:// datasus.saude.gov.br/informacoes-de-saude/tabnet/estatisticas-vitais). This database contains demographic characteristics, geographic location and causes of death that occurred in Brazil in the last decades. Primary, secondary and contributing causes of death have been classified according to the 10th revision of the International Classification of Diseases (ICD-10) since 1999. The underlying cause of death is determined as the "disease of injury which initiates the train of events leading directly to death". When more than one cause or condition is listed in the DC, the underlying cause is determined by the sequence of conditions using standard algorithms provided by the Brazilian $\mathrm{MoH}$ [13]. Population estimation in Brazil has been provided by IBGE. Socio-demographics' statistics of individuals living in Brazil have been based on the 10-year interval census (1980, 1991, 2000 and 2010) and the annual inter-census projections performed by IBGE. Population estimates are available in a web-site (http://ibge.gov.br) stratified by age, gender and geographic localization.

\section{Definition of mortality associated with viral hepatitis}

Deaths related to viral hepatitis were defined by the following ICD-10 codes: hepatitis A [B15.0; B15.9] hepatitis B [B16.2; B16.9; B18.1]; hepatitis C [B17.1; B18.2] and hepatitis Delta [B16.0; B16.1; B18.0; B17.0] other viral hepatitis [B17.2; B17.8; B18.8; B18.9; B19.0; B19.9]. A death due to viral hepatitis was defined by the present of any of the ICD-10 codes described above in any field of the DC (primary, secondary or underlying causes of death). Deaths due to viral coinfection were considered by the presence of two or more codes related to different viral hepatitis infections in the DC. An exception was hepatitis Delta, formally known as hepatitis B and Delta coinfection, which was analyzed separately from hepatitis B.

\section{Mortality rates calculation}

Mortality rates due to viral hepatitis in Brazil were analyzed in a 7-year period: from 2008 (after an improvement in quality in cause-of-death information) to 2014 (last year available at the time of the analysis for this paper). Crude and age-standardized mortality rates, expressed per 100,000 inhabitants, were calculated for Brazil and its federative units and macro-regions. The crude mortality rate was calculated as the ratio between total number of deaths due to hepatitis and estimated population. The age-standardized mortality rate was calculated using the direct standardization method using a standard population [14]. The World Population Standard (2000-2025) reported by the World Health Organization (WHO) was used as the standard population [15]. The WHO Population Standard was especially defined to reflect the average age structure of the world's population expected from the year 2000-2025. The statistical software R ( R Foundation for Statistical Computing, Vienna, Austria. URL http://www.R-project.org/) and STATA (StataCorp LP, College Station, TX, USA) were used for data management, calculation of mortality rates and its 95\% confidence intervals (CI). Time trends were tested using Poisson regression models with mortality rates as the dependent variable and calendar year as a numerical explanatory variable.

\section{Results}

A total of 8,106,219 deaths were registered in Brazil from January 2008 to December 2014. In this period $0.43 \%(n=34,978)$ of deaths had ICD-10 codes related to viral hepatitis mentioned in primary, secondary or contributing causes of death of their DC. Hepatitis $C$ was the most prevalent (73\%) etiology in individuals who had viral hepatitis as cause of death 
in this period. Presence of viral hepatitis co-infection in the DC was rare $(<2 \%)$. Most individuals who had viral hepatitis as cause of death were male (65\%), aged [median (IQR)] of 58 (49-67) years-old and selfdeclared as Caucasian (61\%). Deaths related to viral hepatitis occurred mostly in the Southeast region (52\%) which is the most populated region in Brazil (Table 1 and Additional file 1: Figure S1).

Age-standardized mortality rate $(95 \% \mathrm{CI})$ due to viral hepatitis was $2.695(2.667-2.724)$ deaths per 100,000 inhabitants in Brazil in this 7-year period
(2008-2014). The distribution of these death rates was not uniform across the country: South region [3.997 (3.911-4.085)] had the higher and the Northeast region [1.261 (1.223-1.301)] the lower agestandardized mortality rates due to viral hepatitis. Mortality rates due to hepatitis $\mathrm{C}$ were 4-fold higher than those associated with hepatitis B in Brazil [1.964 $(1.940-1.989) \quad$ vs $0.500 \quad(0.488-0.512)]$. Agestandardized mortality rates due to hepatitis A $(0.066$ [0.049-0.087]), hepatitis B [0.986 (0.918-1.058)] and hepatitis Delta $[0.220(0.190-0.253)]$ were higher in

Table 1 Demographic characteristics of people who had mention of viral hepatitis in their death certificate from 2008 to 2014

\begin{tabular}{|c|c|c|c|c|c|c|}
\hline & $\begin{array}{l}\text { Hepatitis A } \\
(n=391)\end{array}$ & $\begin{array}{l}\text { Hepatitis B } \\
(n=5992)\end{array}$ & $\begin{array}{l}\text { Hepatitis C } \\
(n=24841)\end{array}$ & $\begin{array}{l}\text { Hepatitis Delta } \\
(n=353)\end{array}$ & $\begin{array}{l}\text { Other Hepatitis } \\
(n=2859)\end{array}$ & $\begin{array}{l}\text { All } \\
(n=34436)\end{array}$ \\
\hline Male gender; n (\%) & $218(55.8)$ & $4516(75.4)$ & $15,730(63.3)$ & $240(68.0)$ & $1657(58.0)$ & $22361(64.9)$ \\
\hline Age; median (IQR) & $52(24-69)$ & $56(46-67)$ & $58(51-67)$ & $45(35-57)$ & $53(39-67)$ & $58(49-67)$ \\
\hline \multicolumn{7}{|l|}{ Age groups; n (\%) } \\
\hline$<20$ years & $79(20.3)$ & $77(1.3)$ & $27(0.1)$ & $13(3.7)$ & $245(8.6)$ & $441(1.3)$ \\
\hline 20-29 years & $36(9.2)$ & $222(3.7)$ & $201(0.8)$ & $42(11.9)$ & $200(7.0)$ & $701(2.0)$ \\
\hline 30-39 years & $33(8.5)$ & $599(10.0)$ & $1216(4.9)$ & $75(21.3)$ & $289(10.1)$ & $2212(6.4)$ \\
\hline 40-49 years & $40(10.3)$ & $1098(18.3)$ & $4088(16.5)$ & $84(23.8)$ & $478(16.7)$ & $5788(16.8)$ \\
\hline $50-59$ years & $47(12.0)$ & $1568(26.2)$ & $7733(31.1)$ & $62(17.6)$ & $546(19.1)$ & $9956(28.9)$ \\
\hline $60-69$ years & $64(16.4)$ & $1231(20.6)$ & $6388(25.7)$ & $35(9.9)$ & $510(17.9)$ & $8228(23.9)$ \\
\hline $70-79$ years & $41(10.5)$ & $830(13.9)$ & $3723(15.0)$ & $28(7.9)$ & $374(13.1)$ & $4996(14.5)$ \\
\hline$>=80$ years & $50(12.8)$ & $364(6.1)$ & $1456(5.9)$ & $14(3.9)$ & $213(7.5)$ & $2097(6.2)$ \\
\hline \multicolumn{7}{|l|}{ Ethnicity; n (\%) } \\
\hline Caucasian & $159(40.7)$ & $3080(51.4)$ & $16,351(65.8)$ & $97(27.5)$ & $1377(48.2)$ & $21,064(61.2)$ \\
\hline miscegination "pardo" & $175(44.8)$ & 1999 (33.4) & $5430(21.9)$ & $197(55.8)$ & $1049(36.7)$ & $8850(25.7)$ \\
\hline African-Black & $31(7.9)$ & $499(8.3)$ & $1712(6.9)$ & $20(5.7)$ & $234(8.2)$ & $2496(7.2)$ \\
\hline Asiatic/Indigenous & $6(1.5)$ & $114(1.9)$ & $177(0.7)$ & $14(4.0)$ & $34(1.2)$ & $345(1.0)$ \\
\hline Missing & $20(5.1)$ & $300(5.0)$ & $1171(4.7)$ & $25(7.0)$ & $165(5.7)$ & $1681(4.9)$ \\
\hline \multicolumn{7}{|c|}{ Education in years of study; n (\%) } \\
\hline$<1$ year & $61(15.6)$ & $518(8.7)$ & $912(3.7)$ & $44(12.5)$ & $303(10.6)$ & $1838(5.3)$ \\
\hline 1 to 3 years & $85(21.7)$ & $1235(20.6)$ & $4210(17.0)$ & $81(23.0)$ & $601(21.0)$ & $6212(18.0)$ \\
\hline 4 to 7 years & $79(20.2)$ & $1330(22.2)$ & $5479(22.1)$ & $91(25.8)$ & $603(21.1)$ & $7582(22.0)$ \\
\hline 8 to 11 years & $48(12.3)$ & $955(15.9)$ & $4837(19.5)$ & $52(14.7)$ & $408(14.3)$ & $6300(18.3)$ \\
\hline$\geq 12$ years & $21(5.4)$ & $480(8.0)$ & $2486(10.0)$ & $13(3.7)$ & $194(6.8)$ & $3194(9.4)$ \\
\hline Missing & $97(24.8)$ & $1474(24.6)$ & $6917(27.7)$ & $72(20.3)$ & $750(26.2)$ & $9310(27.0)$ \\
\hline \multicolumn{7}{|c|}{ Geographic macro-regions; n (\%) } \\
\hline North & $58(14.9)$ & $778(13.0)$ & $1010(4.1)$ & $198(56.1)$ & $391(13.7)$ & $2435(7.1)$ \\
\hline Northeast & $137(35.0)$ & $872(14.6)$ & $2448(9.9)$ & $29(8.2)$ & $609(21.3)$ & 4095 (11.9) \\
\hline Southeast & $128(32.7)$ & $2619(43.7)$ & $13,841(55.7)$ & $76(21.5)$ & 1209 (42.3) & $17873(51.9)$ \\
\hline South & $41(10.5)$ & $1170(19.5)$ & $6448(26.0)$ & $37(10.5)$ & $469(16.4)$ & $8165(23.7)$ \\
\hline Central-West & $27(6.9)$ & $553(9.2)$ & $1094(4.4)$ & $13(3.7)$ & $181(6.3)$ & $1868(5.4)$ \\
\hline
\end{tabular}

Viral hepatitis were classified according to the following ICD-10 codes: Hepatitis A [B15.0; B15.9] Hepatitis B [B16.2; B16.9; B18.1]; Hepatitis C [B17.1; B18.2] and Hepatitis Delta [B16.0; B16.1; B18.0; B17.0] other viral hepatitis [B17.2; B17.8; B18.8; B18.9; B19.0; B19.9]. This analysis considered only people who have only one viral hepatitis ICD-10 code in their DC (mono-infected individuals). Presence of co-infection $(n=552)$ : HAV/HBV $(n=13) ; \mathrm{HAV} / \mathrm{HCV}(n=7) ; \mathrm{HBV} / \mathrm{HCV}(n=518) ;$ $\mathrm{HCV} / \mathrm{HDV}(n=8) ; \mathrm{HAV} / \mathrm{HBV} / \mathrm{HCV}(n=3) ; \mathrm{HBV} / \mathrm{HCV} /$ others viral hepatitis $(n=3)$. Total of deaths $=34,988$. Missing: gender $(n=3)$, age $(n=10)$. Mean population per year (in millions inhabitants): North $=16,145$; Northeast $=54,173$; Southeast $=81,931$; South $=27,956$; Central-West $=14.360$ and Brazil $=194,567$ 
Table 2 Number of deaths, crude and age-standardized mortality rates (per 100,000 inhabitants) [95\% confidence interval] due to viral hepatitis according to the macro-regions in Brazil from 2008 to 2014

\begin{tabular}{|c|c|c|c|c|c|c|}
\hline Region & Hepatitis A & Hepatitis B & Hepatitis C & Hepatitis Delta & Other hepatitis & All \\
\hline \multicolumn{7}{|l|}{ North } \\
\hline Deaths (n) & 59 & 842 & 1071 & 212 & 396 & 2492 \\
\hline Crude MR & 0.052 & 0.745 & 0.948 & 0.196 & 0.350 & 2.205 \\
\hline \multirow[t]{2}{*}{ Age-st-MR [95\% Cl] } & 0.066 & 0.986 & 1.458 & 0.220 & 0.449 & 3.062 \\
\hline & [0.049-0.087] & [0.918-1.058] & [1.370-1.550] & [0.190-0.253] & {$[0.403-0.498]$} & [2.938-3.189] \\
\hline \multicolumn{7}{|l|}{ Northeast } \\
\hline Deaths (n) & 141 & 930 & 2506 & 30 & 617 & 4153 \\
\hline Crude MR & 0.037 & 0.245 & 0.661 & 0.008 & 0.163 & 1.095 \\
\hline Age-st-MR [95\% Cl] & $\begin{array}{l}0.039 \\
{[0.036-0.046]}\end{array}$ & $\begin{array}{l}0.278 \\
{[0.261-0.297]}\end{array}$ & $\begin{array}{l}0.780 \\
{[0.750-0.812]}\end{array}$ & $\begin{array}{l}0.009 \\
{[0.006-0.013]}\end{array}$ & $\begin{array}{l}0.176 \\
{[0.163-0.191]}\end{array}$ & $\begin{array}{l}1.261 \\
{[1.223-1.301]}\end{array}$ \\
\hline \multicolumn{7}{|l|}{ Southeast } \\
\hline Deaths (n) & 139 & 2900 & 14,111 & 78 & 1226 & 18,146 \\
\hline Crude MR & 0.024 & 0.506 & 2.460 & 0.014 & 0.214 & 3.164 \\
\hline \multirow[t]{2}{*}{ Age-st-MR [95\% CI] } & 0.024 & 0.486 & 2.367 & 0.013 & 0.207 & 3.045 \\
\hline & [0.020-0.028] & [0.468-0.504] & {$[2.328-2.406]$} & [0.010-0.016] & [0.195-0.219] & [3.001-3.090] \\
\hline \multicolumn{7}{|l|}{ South } \\
\hline Deaths (n) & 46 & 1285 & 6564 & 40 & 471 & 8281 \\
\hline Crude MR & 0.024 & 0.657 & 3.354 & 0.020 & 0.241 & 4.231 \\
\hline \multirow[t]{2}{*}{ Age-st- MR [95\% Cl] } & 0.023 & 0.621 & 3.163 & 0.019 & 0.230 & 3.997 \\
\hline & [0.017-0.031] & [0.588-0.657] & {$[3.087-3.241]$} & {$[0.014-0.026]$} & {$[0.210-0.252]$} & [3.911-4.085] \\
\hline \multicolumn{7}{|l|}{ Central-West } \\
\hline Deaths (n) & 31 & 592 & 1131 & 13 & 187 & 1906 \\
\hline Crude MR & 0.031 & 0.589 & 1.125 & 0.016 & 0.186 & 1.896 \\
\hline \multirow[t]{2}{*}{ Age-st-MR [95\% Cl] } & 0.035 & 0.662 & 1.284 & 0.018 & 0.208 & 2.151 \\
\hline & {$[0.024-0.050]$} & [0.609-0.718] & [1.209-1.362] & [0.009-0.031] & [0.179-0.241] & [2.054-2.251] \\
\hline \multicolumn{7}{|l|}{ Brazil } \\
\hline Deaths (n) & 416 & 6549 & 25,383 & 373 & 2897 & 34,978 \\
\hline Crude MR & 0.031 & 0.481 & 1.864 & 0.028 & 0.213 & 2.568 \\
\hline \multirow[t]{2}{*}{ Age-st-MR [95\% Cl] } & 0.032 & 0.500 & 1.964 & 0.028 & 0.220 & 2.695 \\
\hline & [0.029-0.035] & {$[0.488-0.512]$} & [1.940-1.989] & {$[0.025-0.031]$} & [0.212-0.229] & [2.667-2.724] \\
\hline
\end{tabular}

Mean population per year (ratio between total population from 2008 to 2014 and 7 years; expressed in millions inhabitants): North =16,145; Northeast = 54,173;

Southeast $=81,931$; South $=27,956$; Central-West $=14.360$ and Brazil $=194.567$. Crude mortality rate $=$ number of death $/$ mean population $* 7$ (number of years). Agest-MR, age-standardized mortality rate; MR, mortality rate. $N=552$ patients had co-infection (more than one viral hepatitis ICD-10 codes in their death certificate: HAV/ $\mathrm{HBV}(n=13) ; \mathrm{HAV} / \mathrm{HCV}(n=7) ; \mathrm{HBV} / \mathrm{HCV}(n=518) ; \mathrm{HCV} / \mathrm{HDV}(n=8) ; \mathrm{HAV} / \mathrm{HBV} / \mathrm{HCV}(n=3) ; \mathrm{HBV} / \mathrm{HCV} /$ others viral hepatitis $(n=3)$. In patients with missing age $(n=10)$, it was not possible to calculate adjusted-mortality rate

the Brazilian North region compared to others regions. South $[3.163(3.087-3.241)]$ and Southeast [2.367 (2.328-2.406)] were the top ranking regions for age-standardized mortality rates associated with hepatitis C. Table 2 summarizes the number of deaths and crude / age-standardized mortality rates due to viral hepatitis according to macro-regions in Brazil from 2008 to 2014 . In overall, the mortality rates related to viral hepatitis have decreased in 5.5\% from 2008 to 2014 [2.764 (2.685-2.844) to $2.612(2.542-2.684)$ per 100,000 inhabitants]. However, there was a nonsignificant trend ( $p$ value $>0.05$ ) for annual increasing or decreasing mortality rates in all Brazilian macroregions from 2008 to 2014. Additional file 1 Table S1 describes the annual percent change after agestandardization of mortality rates related to each type viral hepatitis according to the Brazilian macroregions.

The top ranking Brazilian federative units for agestandardized mortality rates [official abbreviation for the state $=$ MR per 100,000 inhabitants $(95 \% \mathrm{CI})$ related to viral hepatitis were Acre [AC $=12.885$ (11.698-14.172)], Rio Grande do Sul $[\mathrm{RS}=6.187$ (6.023-6.356) $]$ and Amazonas $[\mathrm{AM}=4.170(3.858-$ 
4.504)]. On the other hand, Ceará $[C E=0.764$ (0.692-0.842)], Piauí [PI $=0.829(0.705-0.969)]$ and Paraíba $[\mathrm{PB}=0.854(0.743-0.978)]$ had the lowest mortality rates associated with viral hepatitis (Table 3 and Fig. 1). As for hepatitis A, B and Delta, the top mortality rates were observed in federative units located in the North region: (i) for hepatitis A: $\mathrm{AC}=0.114$ (0.034-0.311), Rondônia $(\mathrm{RO})=0.091$ $(0.037-0.198)$ and Roraima (RR) $=0.080 \quad(0.016-$ 0.421); (ii) for hepatitis $\mathrm{B}$ : $\mathrm{AC}=4.334(3.677-5.089)$; $\mathrm{RO}=1.682(1.416-1.993)$ and $\mathrm{AM}=1.542(1.357-$ 1.748); (iii) for hepatitis Delta: $\mathrm{AC}=1.449$ (1.0981.895); $\mathrm{AM}=0.553(0.458-0.667)$ and Roraima $(R R)=0.184(0.048-0.584)$. Considering hepatitis $C$, the highest mortality rates were distributed across the country: $\mathrm{AC}=6.927(6.030-7.929)$ in North;
RS $=5.370(5.218-5.527)$ in South and São Paulo $(\mathrm{SP})=3.046(2.984-3.109)$ in Southeast region. The northern Brazil's federative unit called Acre (AC) had the higher mortality rates for hepatitis $\mathrm{A}, \mathrm{B}, \mathrm{C}$ and Delta (Table 4 and Fig. 2). The number of deaths and crude mortality rates due to viral hepatitis A, B, C and Delta according to federate unit in Brazil in the 7-year period of analysis were summarized in the Additional file 1 Table S2. Age-standardized mortality rates due to viral hepatitis by year according to the Brazilian macro-regions were plotted in the Additional file 1: Figure S2.

\section{Discussion}

The present study highlighted the age-standardized mortality rates related to viral hepatitis in Brazil in a 7-year

Table 3 Number of deaths, crude and age-standardized mortality rates (per 100,000 inhabitants) [95\% confidence interval] due to viral hepatitis according to the federative units in Brazil from 2008 to 2014

\begin{tabular}{|c|c|c|c|c|c|}
\hline Macro-region & Federative Unit & $\begin{array}{l}\text { Mean population } \\
\text { per year }\end{array}$ & Number of deaths & $\begin{array}{l}\text { Crude mortality } \\
\text { rates }\end{array}$ & Age-standardized mortality rates $[95 \% \mathrm{Cl}]$ \\
\hline \multirow[t]{7}{*}{ North } & Acre $(A C)$ & 739,518 & 466 & 9.002 & 12.885 [11.698-14.172] \\
\hline & Amazonas (AM) & $3,575,067$ & 737 & 2.945 & $4.170[3.858-4.504]$ \\
\hline & Amapa (AP) & 682,303 & 48 & 1.005 & $1.926[1.396-2.609]$ \\
\hline & Para (PA) & $7,698,641$ & 748 & 1.388 & $2.000[1.855-2.154]$ \\
\hline & Rondônia (RO) & $1,600,496$ & 310 & 2.767 & $3.576[3.176-4.020]$ \\
\hline & Roraima (RR) & 457,143 & 68 & 2.125 & $3.282[2.500-4.280]$ \\
\hline & Tocantins (TO) & $1,392,251$ & 115 & 1.180 & $1.438[1.183-1.734]$ \\
\hline \multirow[t]{9}{*}{ Northeast } & Alagoas (AL) & $3,191,489$ & 231 & 1.034 & $1.308[1.143-1.491]$ \\
\hline & Bahia (BA) & $1,4512,661$ & 1215 & 1.196 & $1.344[1.269-1.422]$ \\
\hline & Ceara (CE) & $8,604,602$ & 415 & 0.689 & $0.764[0.692-0.842]$ \\
\hline & Maranhão (MA) & $6,609,808$ & 527 & 1.139 & $1.487[1.361-1.621]$ \\
\hline & Paraiba (PB) & $3,820,185$ & 215 & 0.804 & $0.854[0.743-0.978]$ \\
\hline & Pernambuco (PE) & $8,948,388$ & 1016 & 1.622 & 1.826 [1.715-1.942] \\
\hline & Piaui (PI) & $3,152,709$ & 160 & 0.725 & $0.829[0.705-0.969]$ \\
\hline & Rio Grande do Norte (RN) & $3,232,637$ & 229 & 1.012 & 1.147 [1.003-1.307] \\
\hline & Sergipe (SE) & $2,100,840$ & 145 & 0.986 & 1.206 [1.016-1.423] \\
\hline \multirow[t]{4}{*}{ Southeast } & Espirito Santo (ES) & $36,15,218$ & 516 & 2.039 & 2.153 [1.970-2.349] \\
\hline & Minas Gerais (MG) & $20,050,125$ & 2000 & 1.425 & 1.397 [1.336-1.460] \\
\hline & Rio de Janeiro (RJ) & $16,149,068$ & 4082 & 3.611 & 3.248 [3.149-3.350] \\
\hline & São Paulo (SP) & $42,116,780$ & 11,548 & 3.917 & 3.797 [3.728-3.868] \\
\hline \multirow[t]{3}{*}{ South } & Parana (PR) & $10,696,240$ & 1630 & 2.177 & $2.163[2.059-2.271]$ \\
\hline & Rio Grande do Sul (RS) & $10,906,189$ & 5399 & 7.072 & 6.187 [6.023-6.356] \\
\hline & Santa Catarina (SC) & $6,353,717$ & 1252 & 2.815 & 2.773 [2.620-2.933] \\
\hline \multirow[t]{4}{*}{ Central-West } & Distrito Federal (DF) & $2,661,654$ & 354 & 1.900 & $2.349[2.105-2.616]$ \\
\hline & Goias (GO) & $6,137,736$ & 803 & 1.869 & $2.053[1.912-2.203]$ \\
\hline & Mato Grosso do Sul (MS) & $2,476,719$ & 375 & 2.163 & $2.347[2.114-2.600]$ \\
\hline & Mato Grosso (MT) & $3,084,790$ & 374 & 1.732 & $2.023[1.819-2.247]$ \\
\hline
\end{tabular}

Mean population by year $=$ ratio between total population from 2008 to 2014 and 7 years. Crude mortality rate $=$ number of death $/$ mean population * 7 (number of years) 


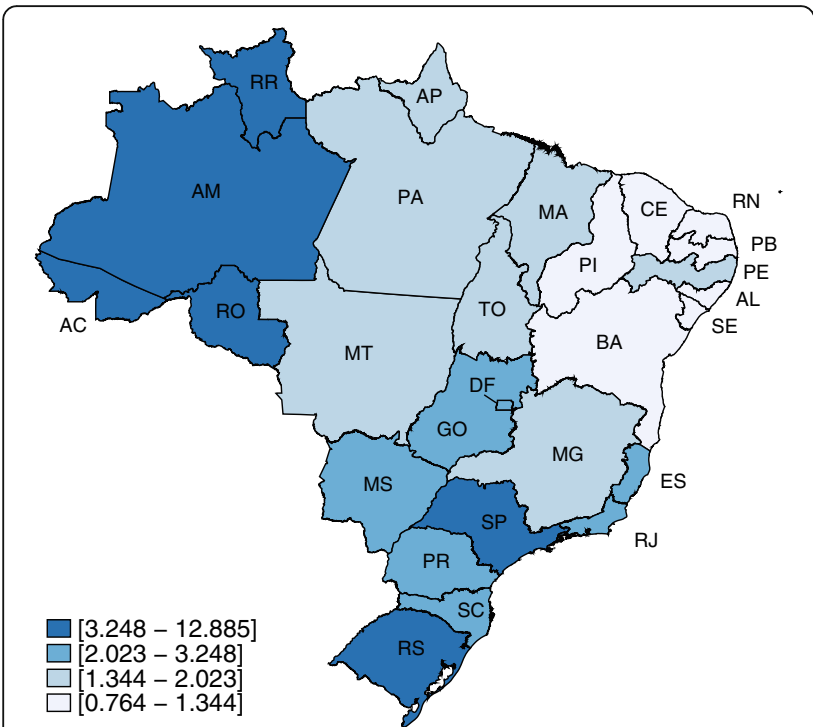

Fig. 1 Age-standardized mortality rates (per 100,000 inhabitants) associated with viral hepatitis from 2008 to 2014 in Brazilian federative units. [AC, Acre; AL, Alagoas; AM, Amazonas; AP, Amapa; BA, Bahia; CE, Ceara; DF, Distrito Federal; ES, Espirito Santo; GO, Goiânia; Ma, Maranhão; MG, Minas Gerais; MS, Mato Grosso do Sul; PA, Para; PB, Paraiba; PE, Pernambuco; PI, Piaui; PR, Parana; RJ, Rio de Janeiro; RN, Rio Grande do Norte; RO, Rondônia; RR, Roraima; RS, Rio Grande do Sul; SC, Santa Catarina; SE, Sergipe; SP, São Paulo; TO,

Tocantins]. Density of colors expressed in quartiles

period (from 2008 to 2014). Despite relative low agestandardized mortality rates associated with viral hepatitis, Brazil is a large and complex country with nearly 200 million inhabitants and striking regional differences ranging from the richer South and Southeast, the poorer North and Northeast and the expanding Central-West region. This nationwide death registry analysis showed that viral hepatitis were associated with over 34,000 deaths in this period.

A Brazilian study reported that more than $90 \%$ of northern and northeast population tested positive for hepatitis A IgG antibodies [16]. This study analyzed of the mortality rates due to hepatitis A in Brazil from 1980 to 2002 reporting higher rates in Northern region and a progressive decrease (from 0.20 to 0.02 per 100,000 inhabitants) in hepatitis A mortality rates in all Brazilian macro-regions [16]. The present study described similar higher mortality rates in North and Northeast compared to South and Southeast regions. However, we described higher age- standardized mortality rates $[0.032(0.029-0.035)]$ in a 7 -years period and a non-significant time trend. These results are alarming particularly because of the inverse correlation between hepatitis A and socioeconomic standards [17]. Regarding hepatitis B, Brazil has been classified as of low endemicity with an estimated prevalence of $0.65 \%$ (95\% CI 0.65-0.66) [18]. However, prevalence of hepatitis B and
Delta has a heterogenic distribution across the country, with higher concentration in Northern Brazil [19]. In the general population, prevalence of HBsAg marker ranged from $0.57 \%$ in the Southeast to $6.2 \%$ in the North region [20]. More than 60,000 and 70,000 cases of hepatitis B and $C$, respectively, were registered at the Brazilian National System for Surveillance and Control of Diseases from 2012 to 2015 (http://portalsinan.saude.gov.br/hepatites-virais), respectively. A Brazilian study that analyzed 2936 individuals living in Rio de Janeiro (Southeast region) showed a prevalence of $0.14 \%(0.01-$ $0.30)$ hepatitis B and $0.44 \%(0.20-0.68)$ hepatitis $C$ infection [21]. However, a higher prevalence of chronic hepatitis C [1.38\% (95\% CI: 1.12-1.64)] was reported in a second cross-sectional population-based study that analyzed more than 19000 individuals over the country [22]. In addition, using mathematic models, the Brazilian Ministry of Health estimated that around 1,450,000 people are living with hepatitis $C$ [6].

According to the Global Hepatitis Report from the WHO, the global number of deaths related to viral hepatitis increased from 1.10 million deaths in 2000 to 1.34 million deaths in 2015 [23]. In addition, according to the Global Burden Disease (GBD), viral hepatitis has been associated with disability adjusted life year worldwide [24] and the mortality rates $(95 \% \mathrm{CI})$ from cirrhosis due to hepatitis $\mathrm{B}$ and $\mathrm{C}$ were 8.1 (5.36-11.49) and 1.7 (0.63.4) per 100,000 inhabitants in Brazil in 2013 [25]. Mortality rates from viral hepatitis $B$ and $C$ have increased from 1999 to 2007 in the United States [26]. Moreover, national hospitalization and inpatient mortality rates due to hepatitis $C$ have increased in the last decade [27]. Comparing our data with those from GBD 188 countries [17], age- standardized mortality-rate was lower for hepatitis B and higher for hepatitis C [28]. Our results show that Brazilian mortality rates widely varied according to geographical localization. Hence, southeast and south regions presented higher mortality rates due to hepatitis $\mathrm{C}$ than others regions. These results might be explained by higher rates of diagnosis since these populations have a better access to the health care systems [29] and/or by higher incidence of hepatitis $C$ [30]. Higher mortality rates in few Brazilian federations units, such as AC and RS, might be related to a higher prevalence of injection drug users in these regions [31]. Northern Brazil, especially the Amazon Basin, is an endemic area for hepatitis Delta with up to $30 \%$ of hepatitis Delta virus infection in patients with hepatitis B [32]. This finding might explain the higher mortality rates due to hepatitis B and Delta in North compared to others Brazilian macro-regions. However, mortality rates comparisons between regions and/or countries should be interpreted with caution due to a considerable variability in death report 
Table 4 Age-standardized mortality rates (per 100,000 inhabitants) [95\% confidence interval] due to viral hepatitis according to the federative units in Brazil from 2008 to 2014

\begin{tabular}{|c|c|c|c|c|c|}
\hline Macro-region & Federative Unit & Hepatitis A & Hepatitis B & Hepatitis C & Hepatitis Delta \\
\hline \multirow[t]{7}{*}{ North } & Acre $(A C)$ & $0.114[0.034-0.311]$ & 4.334 [3.677-5.089] & 6.927 [6.030-7.929] & $1.449[1.098-1.895]$ \\
\hline & Amazonas (AM) & $0.014[0.004-0.049]$ & $1.542[1.357-1.748]$ & 1.625 [1.420-1.853] & $0.553[0.458-0.667]$ \\
\hline & Amapa (AP) & $0.016[0.001-0.232]$ & $0.273[0.105-0.610]$ & 1.299 [0.866-1.890] & NA \\
\hline & Para (PA) & $0.071[0.047-0.105]$ & $0.393[0.331-0.464]$ & 1.169 [1.056-1.290] & 0.018 [0.007-0.039] \\
\hline & Rondônia (RO) & $0.091[0.037-0.198]$ & 1.682 [1.416-1.993] & $1.430[1.176-1.731]$ & $0.112[0.052-0.224]$ \\
\hline & Roraima (RR) & $0.080[0.016-0.421]$ & 1.323 [0.855-2.013] & 1.193 [0.726-1.895] & $0.184[0.048-0.584]$ \\
\hline & Tocantins (TO) & $0.106[0.048-0.209]$ & $0.652[0.484-0.861]$ & $0.372[0.246-0.542]$ & $0.038[0.008-0.116]$ \\
\hline \multirow[t]{9}{*}{ Northeast } & Alagoas (AL) & $0.025[0.008-0.063]$ & $0.294[0.219-0.387]$ & $0.818[0.687-0.967]$ & $0.018[0.004-0.054]$ \\
\hline & Bahia (BA) & $0.021[0.013-0.033]$ & $0.242[0.211-0.277]$ & 0.893 [0.831-0.958] & $0.005[0.002-0.013]$ \\
\hline & Ceara (CE) & $0.033[0.021-0.052]$ & $0.180[0.146-0.219]$ & $0.442[0.386-0.503]$ & $0.003[0.001-0.013]$ \\
\hline & Maranhão (MA) & $0.076[0.051-0.111]$ & $0.446[0.379-0.523]$ & $0.652[0.568-0.745]$ & $0.027[0.013-0.051]$ \\
\hline & Paraiba (PB) & $0.051[0.028-0.087]$ & $0.164[0.118-0.222]$ & $0.509[0.423-0.608]$ & $0.004[0.001-0.024]$ \\
\hline & Pernambuco (PE) & $0.037[0.023-0.053]$ & $0.353[0.306-0.406]$ & 1.308 [1.214-1.408] & $0.008[0.003-0.020]$ \\
\hline & Piaui (PI) & $0.042[0.019-0.183]$ & $0.295[0.224-0.383]$ & $0.375[0.293-0.475]$ & $0.011[0.001-0.040]$ \\
\hline & Rio Grande do Norte (RN) & $0.078[0.045-0.129]$ & $0.246[0.182-0.327]$ & $0.698[0.595-0.826]$ & $0.010[0.001-0.039]$ \\
\hline & Sergipe (SE) & $0.014[0.002-0.059]$ & $0.395[0.291-0.526]$ & $0.630[0.493-0.795]$ & NA \\
\hline \multirow[t]{4}{*}{ Southeast } & Espirito Santo (ES) & $0.012[0.002-0.038]$ & $0.726[0.622-0.844]$ & 1.242 [1.104-1.394] & $0.048[0.025-0.086]$ \\
\hline & Minas Gerais (MG) & $0.021[0.014-0.030]$ & $0.362[0.332-0.395]$ & $0.881[0.833-0.931]$ & 0.012 [0.007-0.019] \\
\hline & Rio de Janeiro (RJ) & $0.023[0.015-0.034]$ & $0.468[0.431-0.508]$ & $2.605[2.516-2.696]$ & $0.013[0.007-0.021]$ \\
\hline & São Paulo (SP) & $0.027[0.021-0.033]$ & $0.533[0.508-0.560]$ & 3.046 [2.984-3.109] & $0.011[0.007-0.015]$ \\
\hline \multirow[t]{3}{*}{ South } & Parana (PR) & $0.016[0.008-0.028]$ & 0.649 [0.593-0.710] & 1.295 [1.215-1.379] & $0.020[0.011-0.033]$ \\
\hline & Rio Grande do Sul (RS) & $0.030[0.020-0.046]$ & $0.604[0.553-0.659]$ & $5.370[5.218-5.527]$ & $0.011[0.005-0.022]$ \\
\hline & Santa Catarina (SC) & $0.021[0.010-0.042]$ & 0.609 [0.539-0.687] & 1.965 [1.837-2.100] & $0.033[0.019-0.054]$ \\
\hline \multirow[t]{4}{*}{ Central-West } & Distrito Federal (DF) & $0.025[0.006-0.072]$ & $0.687[0.558-0.840]$ & 1.473 [1.281-1.688] & $0.027[0.007-0.075]$ \\
\hline & Goias (GO) & $0.024[0.011-0.046]$ & $0.615[0.540-0.700]$ & 1.252 [1.142-1.370] & $0.011[0.003-0.028]$ \\
\hline & Mato Grosso do Sul (MS) & $0.020[0.004-0.060]$ & $0.589[0.476-0.722]$ & 1.596 [1.405-1.807] & NA \\
\hline & Mato Grosso (MT) & $0.082[0.044-0.142]$ & $0.809[0.682-0.955]$ & $0.916[0.781-1.072]$ & $0.026[0.008-0.069]$ \\
\hline
\end{tabular}

NA: Not applicable given that no cases were reported. Mean population per year for federative units are described in Table 3

processes worldwide and in the methods used for data analysis. In the present study, death due to viral hepatitis was defined by the presence of ICD-10 codes in the primary, secondary or contributing causes of death in the DC; mortality rates were age- standardized using the direct method and the standard population proposed by WHO which was estimated as an average world population age-structure constructed for the period 2000-2025. In a sensitivity analysis, we reported similar results on age-standardized mortality rates related to viral hepatitis and a non-significant trend for annual increasing or decreasing mortality rates in all Brazilian macro-regions from 2008 to 2014 when using the Brazilian population from year 2008 as the standard population (Additional file 1: Table S3).

Considering the current age-standardized mortality rates and the population projected by IBGE for the next
50 years, more than 190,000 deaths associated with viral hepatitis might occur from 2020 to 2060 in Brazil, most of them (up to 154,000) due to hepatitis $\mathrm{C}$ assuming no improvements in treatment and/or other public health strategies. The Viral Hepatitis National Program from the Brazilian $\mathrm{MoH}$ has been prioritizing health policies to improve the cascade of hepatitis $B$ and $C$, as well as to implement cost-effective prevention programs and novel treatment for viral hepatitis. Accurate point-ofcare tests are available in Brazil for hepatitis B screening [33] and vaccination of newborns has been part of the National Immunization Program since 1998. Currently, hepatitis B vaccine is widely available for individuals up to 49 years-old [34]. Vaccination of difficult-to-access populations, such as those living in rural areas or in the Amazon forest, is still a challenge to the prevention of hepatitis B and Delta. Despite the satisfactory vaccine 

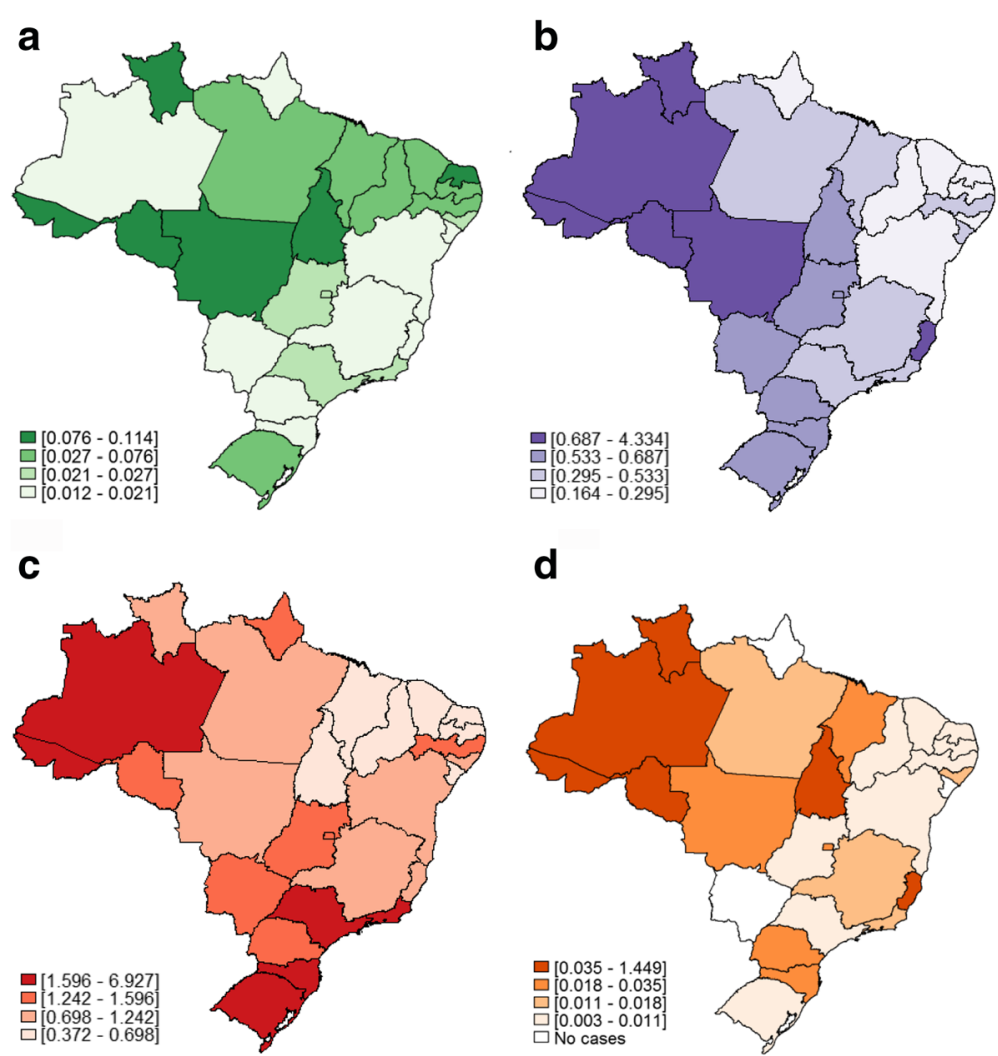

Fig. 2 Age-standardized mortality rates (per 100.000 inhabitants) related to: a hepatitis A [B15.0; B15.9]; b hepatitis B [B16.2; B16.9; B18.1]; c hepatitis C [B17.1; B18.2] and d hepatitis Delta [B16.0; B16.1; B18.0; B17.0] according to federative units in Brazil from 2008 to 2014. Density of colors expressed in quartiles

coverage, others prevention and treatment interventions are available, but insufficiently implemented in Brazil. First-line drugs to control hepatitis B and Delta has been delivered free of charge by the Brazilian public health system (Sistema Único de Saúde - SUS) [35]. Nucleos(t)ide analogues (NUCs) are available for chronic hepatitis B treatment since 2009. In addition, hepatitis C has been considered as a public health issue by Brazilian health authorities [36]. Despite the absence of a vaccine, point-of-care tests have been used for screening [37] and non-invasive tests have been available for fibrosis staging in Brazilian citizens living with chronic hepatitis $C$ [38]. Improvement in identification of $\mathrm{HCV}$-infected individuals and treatment of those with fibrosis stage $\mathrm{F} \geq 2$ with highly effective drugs (sustained virological response of $85 \%$ ) might lead to $90 \%$ reduction in hepatitis burden by year 2030 in Brazil [12]. The $\mathrm{BMoH}$ had an intense negotiation with pharmaceutical companies resulting in more than $90 \%$ discount over international prices for direct-aging antivirals drugs (DAAs), such as sofosbuvir, daclastavir and simeprevir. These DAAs were recently incorporated by the public health system to be delivered for free to the Brazilian population aiming to tackle chronic hepatitis $C$ and to prevent its complications $[7,39]$. The surveillance of mortality rates seems to be one of the most important strategies to guide viral hepatitis health policies. The relative short period of free-delivery of NUCs and DAAs by the Brazilian $\mathrm{MoH}$ might explain the nonsignificant decrease in mortality rates in the last decade. However, trends of annual mortality rates can be used in the future to evaluate the efficacy of recently implemented strategies, such as hepatitis $C$ eradication by DAAs.

The present study has several limitations, mainly associated with the absence of standardization by gender and the lack of high quality of death cause registration in few Brazilian regions. However, death count coverage in Brazil has increased from $80 \%$ in $1980-1991$ to more than $95 \%$ in $2000-2010$ [40]. In addition, cause-of-death information has highly improved in Brazil after 2006 likely resulting from investments in public health care system and death report process in this country [41]. Accordingly, we analyzed mortality data from 2008 onwards to avoid the use and interpretation of low-quality data. The proportion of deaths from ill-defined or unknown causes of death [ICD-10: R00-R99] might be used as an indicator of the quality of cause-of-death data [42]. Quality of mortality data seems to be improving in the last years in Brazil: from 2000 to 2012, the proportion of 
ill-defined or unknown causes of death has decreased from $14.3-6.3 \%$ of deaths [11]. In addition, the number of ill-defined deaths and the mortality rates of unknown cause of deaths have decreased by $45 \%$ and $52 \%$, respectively [11]. These decrease in proportion, absolute number of deaths and mortality rates were observed in all Brazilian macro-regions. However, there are still large regional differences in mortality report in Brazil: data quality seems to be better in South and Southeast compared to others regions [43]. Gender differences in mortality and life expectancy vary by country. However, in most countries, mortality rates are higher in men compared to women. Analysis of mortality rates with sex-standardization would be important for implementation of different health strategies in male and female population.

The major strength of this study was the estimation of the burden of viral hepatitis mortality analyzing individual data in a nationwide database (SIM) provided by the Brazilian MoH. SIM registers death causes based on DC classified by ICD codes since 1979 (ICD-9 from 1979 to 1995 and ICD-10 from 1996 onwards). Since 1999, primary, secondary and contributing causes of death have been available in the database. Mortality data has been systematically updated by the Brazilian Unified Health System Information Technology Department. Death by viral hepatitis was defined as presence of the specific ICD-10 in any field of the DC to avoid underestimation of mortality rates. In addition, mortality rates were adjusted for age using the WHO world standard population that allows comparison of our data with different countries worldwide. Moreover, the consideration of Brazil as a whole as well as its macro-regions can contribute to a greater understanding of the burden of liver disease in the country and perhaps worldwide.

\section{Conclusion}

In summary, this study described the age- standardized mortality rates associated with viral hepatitis in Brazil and its micro and macro-regions from 2008 to 2012. Viral hepatitis were associated with up to 22,000 deaths, most of them related to hepatitis C. Mortality rates were not homogeneous across the country, suggesting that health policies, prevention programs and novel treatments should be tailored in Brazil according to geographical location.

\section{Additional file}

Additional file 1: Supplementary materials: Table S1. Age-standardized mortality rates $(\mathrm{aMR})$ and annual percent change $(\% \Delta)$ after age-standardization from mortality rates related to viral hepatitis according to Brazilian macro-regions. Table S2. Number of deaths and crude mortality rates (per 100,000 inhabitants) related to hepatitis A, B, C and Delta according to the federative units in Brazil from 2008 to 2014. Table S3. Age-standardized mortality rates (per 100.000 inhabitants) [95\% confidence interval] due to viral hepatitis according to the macro-regions and federative units in Brazil from 2008 to 2014 using the Brazilian population from year 2008 as the standard population. Figure S1. Graphical representation of population distribution in the federative units of Brazil. Population expressed as mean of millions inhabitants per year from 2008 to 2014. Figure S2. Age-standardized mortality rates (per 100.000 inhabitants) related to viral hepatitis by year according to the Brazilian macro-regions. (DOCX 1674 kb)

\section{Abbreviations}

Cl: Confidence interval; DAA: Direct acting agents; DATASUS: Brazilian Unified Health System Information Technology Department; DC: Death certificate;

EU: European Union; IBGE: Brazilian Institute of Geography and Statistics; ICD: International Classification of Diseases; MoH: Ministry of Health;

NUCs: Nucleos(t)ide analogues; SIM: Sistema de Informação sobre Mortalidade - National Registry of Death database; SINAN: Sistema de Informação de Agravos de Notificação; SUS: Sistema Único de Saúde; WHO: World Health Organization

\section{Funding}

This work was supported by funding from: Conselho Nacional de Desenvolvimento Cientifico e Tecnologico (CNPq) / Bolsa Jovem Talento (BJT) - Programa Ciências Sem Fronteiras under grant 301,520/2014-3; from Fundação Carlos Chagas Filho de Amparo à Pesquisa do Estado do Rio de Janeiro (FAPERJ) and Newton Fund RCUK-CONFAP Research Partnerships call, FAPERJ under grant E-26/170.021/2015 (Brazil) and Medical Research Council (MRC) grant reference MR/M026515/1 (UK).

\section{Availability of data and materials}

Data from causes of mortality in Brazil have been published anonymously in a web-based public domain (http://datasus.saude.gov.br/informacoes-de-saude/ tabnet/estatisticas-vitais). The datasets generated and/or analyzed during the current study are available in the following URL: http://datasus.saude.gov.br/ informacoes-de-saude/tabnet/estatisticas-vitais.

\section{Authors' contributions}

HP: study concept and design; analysis and interpretation of data; statistical analysis; drafting and critical revision of the manuscript. AGP: acquisition of data; analysis and interpretation of data and critical revision of the manuscript. PML, RC, CH, JF, CR and SWC: interpretation of data and critical revision of the manuscript. VGV and BG: study supervision, interpretation of data and critical revision of the manuscript. All authors read and approved the final manuscript.

\section{Ethics approval and consent to participate}

The Brazilian National Death Registry database (Sistema de Informação sobre Mortalidade - SIM) from the Brazilian Unified Health System Information Technology Department (DATASUS) is an open-source and web available database (http://datasus.saude.gov.br/informacoes-de-saude/tabnet/estatisticas-vitais) where all deaths causes have been registered in Brazil since 1979. Data were analyzed anonymously and the study was approved with waiver of informed consent by the Ethical Committee from Instituto Nacional de Infectologia Evandro Chagas (IRB 51736815.3.0000.5262).

\section{Consent for publication}

Not applicable.

Competing interests

The authors declare that there is no conflict of interest regarding to this topic.

\section{Publisher's Note}

Springer Nature remains neutral with regard to jurisdictional claims in published maps and institutional affiliations.

\section{Author details}

${ }^{1}$ Fundação Oswaldo Cruz (FIOCRUZ), Instituto Nacional de Infectologia Evandro Chagas (INI), Laboratório de Pesquisa Clínica em DST e AIDS (LAPCLIN-AIDS), Rio de Janeiro, Brazil. 'Fundação Oswaldo Cruz (FIOCRUZ), Programa de Computação Científica (PROCC), Rio de Janeiro, Brazil. ${ }^{3}$ Institute of Health Research, Peninsula Technology Assessment Group (PenTAG), 
Evidence Synthesis and Modelling for Health Improvement (ESMI), University of Exeter Medical School, University of Exeter, England, UK.

\section{Received: 8 March 2017 Accepted: 18 July 2017} Published online: 31 July 2017

\section{References}

1. Lozano R, Naghavi M, Foreman K, Lim S, Shibuya K, Aboyans V, Abraham J, Adair T, Aggarwal R, Ahn SY, et al. Global and regional mortality from 235 causes of death for 20 age groups in 1990 and 2010: a systematic analysis for the global burden of disease study 2010. Lancet. 2012;380:2095-128.

2. Mendez-Sanchez N, Villa AR, Chavez-Tapia NC, Ponciano-Rodriguez G, AlmedaValdes $\mathrm{P}$, Gonzalez D, Uribe M. Trends in liver disease prevalence in Mexico from 2005 to 2050 through mortality data. Ann Hepatol. 2005;4:52-5.

3. Ferrarese A, Zanetto A, Gambato M, Bortoluzzi I, Nadal E, Germani G Senzolo M, Burra P, Russo FP. Liver transplantation for viral hepatitis in 2015. World J Gastroenterol. 2016;22:1570-81.

4. Aggarwal R, Goel A. Hepatitis a: epidemiology in resource-poor countries. Curr Opin Infect Dis. 2015;28:488-96.

5. Blasco-Perrin H, Abravanel F, Blasco-Baque V, Peron JM. Hepatitis E, the neglected one. Liver Int. 2016;36(Suppl 1):130-4.

6. Brasil. Epidemiological Report of Viral Hepatitis [Boletim Epidemiológico de Hepatites Virais]. Brasília, Brazil: Brazilian Ministry of Health [Ministerio da Saude do Brasil]; 2015.

7. Mesquita F, Santos ME, Benzaken A, Correa RG, Cattapan E, Sereno LS, Naveira MC. The Brazilian comprehensive response to hepatitis C: from strategic thinking to access to interferon-free therapy. BMC Public Health. 2016;16:1132.

8. Braga WS, de Oliveira CM, de Araujo JR, Castilho Mda C, Rocha JM, Gimaque JB, Silva ML, Vasconcelos HL, Ramasawmy R, Parana R. Chronic HDV/HBV coinfection: predictors of disease stage - a case series of HDV-3 patients. J Hepatol. 2014:61:1205-11.

9. Couto I, Victoria M, Veloso VG, Rodrigues L, Grinsztejn B, Lacerda M, Victoria $\mathrm{F}$, Perazzo H. Prevalence and predictors for compensated advanced chronic liver disease (c-ACLD) in patients with chronic Hepatitis Delta virus (HDV) infection. PLoS One. 2017;12:e0174453.

10. Nader LA, de Mattos AA, Bastos GA. Burden of liver disease in Brazil. Liver Int. 2014:34:844-9.

11. Perazzo H, Pacheco AG, De Boni R, Luz P, Fittipaldi J, Cardoso S, Grinsztejn $B$, Veloso V. Age-standardized mortality rates related to cirrhosis in Brazil from 2000 to 2012: a nationwide analysis. Ann Hepatol. 2017(16):269-78.

12. Ferreira PR, Brandao-Mello CE, Estes C, Goncales Junior FL, Coelho HS, Razavi $\mathrm{H}$, Cheinquer $\mathrm{H}$, Wolff FH, Ferraz ML, Pessoa MG, et al. Disease burden of chronic hepatitis C in Brazil. Braz J Infect Dis. 2015;19:363-8.

13. Brasil. Guideline for information of cause of death in the death certificate [Manual de instruções para o preenchimento da declaração de obito]. Brasilia (DF): Brazilian Ministry of Health [Ministerio da Saude do Brasil]; 2001.

14. Naing NN. Easy way to learn standardization: direct and indirect methods. Malays J Med Sci. 2000;7:10-5.

15. WHO World Population Standard (2000-2025). [http://seer.cancer.gov/ stdpopulations/world.who.html/ stdpopulations /world.who.html].

16. Vitral CL, Gaspar AM, Souto FJ. Epidemiological pattern and mortality rates for hepatitis a in Brazil, 1980-2002-a review. Mem Inst Oswaldo Cruz. 2006; 101:119-27.

17. Zago-Gomes MP, Stantolin GC, Perazzio S, Aikawa KH, Goncalves CS, Pereira FE. Prevalence of anti-hepatits a antibodies in children of different socioeconomic conditions in Vila Velha, ES. Rev Soc Bras Med Trop. 2005;38:285-9.

18. Schweitzer A, Horn J, Mikolajczyk RT, Krause G, Ott JJ. Estimations of worldwide prevalence of chronic hepatitis B virus infection: a systematic review of data published between 1965 and 2013. Lancet. 2015;386:1546-55.

19. Viana S, Parana R, Moreira RC, Compri AP, Macedo V. High prevalence of hepatitis $B$ virus and hepatitis D virus in the western Brazilian Amazon. Am J Trop Med Hyg. 2005;73:808-14

20. Souto FJ. Distribution of hepatitis B infection in Brazil: the epidemiological situation at the beginning of the 21 st century. Rev Soc Bras Med Trop. 2016:49:11-23.

21. Pinto FP, Ferreira OC Jr, Olmedo DB, Precioso PM, Barquette FR, Castilho MC, Silva SG, Porto LC. Prevalence of hepatitis B and C markers in a population of an urban university in Rio de Janeiro, Brazil: a cross-sectional study. Ann Hepatol. 2015;14:815-25.

22. Pereira LM, Martelli CM, Moreira RC, Merchan-Hamman E, Stein AT, Cardoso MR, Figueiredo GM, Montarroyos UR, Braga C, Turchi MD, et al. Prevalence and risk factors of hepatitis C virus infection in Brazil, 2005 through 2009: a cross-sectional study. BMC Infect Dis. 2013;13:60

23. WHO Global hepatitis report 2017 [http://www.who.int/hepatitis/ publications/global-hepatitis-report2017/en/].

24. Global Burden of Disease Study 2013 Collaborators. Global, regional, and national incidence, prevalence, and years lived with disability for 301 acute and chronic diseases and injuries in 188 countries, 1990-2013: a systematic analysis for the global burden of disease study 2013. Lancet. 2015;386:743-800.

25. Institute for Health Metrics and Evaluation. Global Burden Disease Compare [http://vizhub.healthdata.org/gbd-compare].

26. Ly KN, Xing J, Klevens RM, Jiles RB, Ward JW, Holmberg SD. The increasing burden of mortality from viral hepatitis in the United States between 1999 and 2007. Ann Intern Med. 2012;156:271-8.

27. Younossi ZM, Otgonsuren M, Henry L, Arsalla Z, Stepnaova M, Mishra A, Venkatesan C, Hunt S. Inpatient resource utilization, disease severity, mortality and insurance coverage for patients hospitalized for hepatitis $C$ virus in the United States. J Viral Hepat. 2015;22:137-45.

28. GBD 2013 Mortality and Causes of Death Collaborators. Global, regional, and national age-limita specific all-cause and cause-specific mortality for 240 causes of death, 1990-2013: a systematic analysis for the global burden of disease study 2013. Lancet. 2015;385:117-71.

29. Victora CG. Barreto ML, do Carmo Leal M, Monteiro CA, Schmidt MI, Paim J, Bastos Fl, Almeida C, Bahia L, Travassos C et al: health conditions and healthpolicy innovations in Brazil: the way forward. Lancet. 2011;377:2042-53.

30. Hanus JS, Ceretta LB, Simoes PW, Tuon L. Incidence of hepatitis C in Brazil. Rev Soc Bras Med Trop. 2015:48:665-73.

31. Oliveira Mde L, Bastos Fl, Telles PR, Hacker Mde A, Oliveira SA, Miguel JC, Yoshida CF. Epidemiological and genetic analyses of hepatitis $C$ virus transmission among young/short- and long-term injecting drug users from Rio de Janeiro, Brazil. J Clin Virol. 2009:44:200-6.

32. Crispim MA, Fraiji NA, Campello SC, Schriefer NA, Stefani MM, Kiesslich D. Molecular epidemiology of hepatitis B and hepatitis delta viruses circulating in the western Amazon region. North Brazil BMC Infect Dis. 2014;14:94.

33. Cruz HM, Scalioni Lde P, de Paula VS, da Silva EF, do OK MFA, Cruz MS, Bastos Fl, Pollo-Flores P, Leal E, et al. Evaluating HBsAg rapid test performance for different biological samples from low and high infection rate settings \& populations. BMC Infect Dis. 2015;15:548.

34. Barata RB, Ribeiro MC, de Moraes JC, Flannery B. Socioeconomic inequalities and vaccination coverage: results of an immunisation coverage survey in 27 Brazilian capitals, 2007-2008. J Epidemiol Community Health. 2012;66:934-41.

35. Brasil. Guideline for management and treatment of chronic hepatitis B and its co-infections [Protocolo Clinico e Diretrizes Terapêuticas para Tratamento da Hepatite Viral Crônica B e co-infecções]. Brasilia (DF): Brazilian Ministry of Health [Ministerio da Saude do Brasil]; 2014.

36. Castro R, Perazzo H, Grinsztejn B, Veloso VG, Hyde C. Chronic hepatitis C: an overview of evidence on epidemiology and management from a Brazilian perspective. Int J Hepatol. 2015;2015:852968.

37. da Rosa L, Dantas-Correa EB, Narciso-Schiavon JL, Schiavon Lde L. Diagnostic performance of two point-of-care tests for anti-HCV detection. Hepat Mon. 2013;13:e12274.

38. Brasil. The role of hepatic elastography on liver fibrosis staging [Elastografia hepática ultrassônica no diagnóstico da fibrose hepática]. Brasilia (DF): Brazilian Ministry of Health [Ministerio da Saude do Brasil]; 2015.

39. Brasil. Guideline for management and treatment of chronic hepatitis $C$ and its co-infections [Protocolo Clinico e Diretrizes Terapêuticas para Tratamento da Hepatite Viral Crônica C e co-infecções]. Brasilia (DF): Brazilian Ministry of Health [Ministerio da Saude do Brasil]; 2015.

40. de Lima EE, Queiroz BL. Evolution of the deaths registry system in Brazil: associations with changes in the mortality profile, under-registration of death counts, and ill-defined causes of death. Cad Saude Publica. 2014;30:1721-30.

41. Franca E, de Abreu DX, Rao C, Lopez AD. Evaluation of cause-of-death statistics for Brazil, 2002-2004. Int J Epidemiol. 2008;37:891-901.

42. Franca $E$, Campos D, Guimaraes MD, Souza Mde F. Use of verbal autopsy in a national health information system: effects of the investigation of illdefined causes of death on proportional mortality due to injury in small municipalities in Brazil. Popul Health Metr. 2011:9:39.

43. Franca EB, da Cunha CC, Vasconcelos AM, Escalante JJ, de Abreu DX, de Lima RB, de Morais Neto OL. Investigation of ill-defined causes of death: assessment of a program's performance in a state from the northeastern region of Brazil. Rev Bras Epidemiol. 2014;17:119-34. 